\title{
Analysis on the feasibility of small-scale biogas from palm oil mill effluent (POME) - Study case: Palm oil mill in Riau-Indonesia
}

\author{
A P Nuryadi ${ }^{1,2}$, A A Raksodewanto ${ }^{2}, \mathrm{H}_{\text {Susanto }}^{3}$, Y Peryoga $^{2}$ \\ ${ }^{1}$ CAME, RWTH Aachen University, Germany \\ ${ }^{2}$ Laboratory Fuel Technology and Engineering Design-BPPT, 480 Puspiptek, 15314 Indonesia \\ ${ }^{3}$ Centre of Technology for Materials-BPPT, 480 Puspiptek, 15314 Indonesia
}

\begin{abstract}
The province of Riau has the most significant palm oil plantation in Indonesia which has the potential of the palm oil mill effluent (POME). One way to use this liquid waste is by the anaerobic process into biogas to generate electricity. Based on the assumption of calculated liquid waste can produce biogas about $538 \mathrm{~m} 3 /$ hour or equal to 4,600 MJ / hour potentially generate electricity about $1 \mathrm{MW}$. This paper discusses the scheme of the POME Biogas Power Plant project which benefits the palm oil mill which is Built-operate-transfer (BOT) with a duration of 15 years selected as a reference. With this duration obtained IRR of $17.47 \%$ higher than at WACC of $15.61 \%$ and a payback period of 5.63 years. The 15-year duration gives Investor resilience in case of an increase of loan interest rate to $13 \%$ during the repayment period. Also, the use of alternative schemes that may be pursued by biogas products from cleaned digesters is then used as gas fuel to operate diesel generators. Plant Alternative for BOT duration for five years. The project is very feasible to be implemented with a very high IRR (37.56\%) score when compared to WACC $(15.61 \%)$.
\end{abstract}

\section{Introduction}

The palm oil industry has grown tremendously in the recent years and accounted for the most significant percentage of oil and fats production. The 2017 palm oil production forecast remains 38.5 million tons [1], Especially in Indonesia. Palm oil mill effluent (POME), oil kernel oil (PKO), palm empty fruit bunch (EFB), palm oil palm shell (shell), and oil palm fibre (fibre) from CPO as well as palm oil mills. For 20-23\% EFB, 5-6\% PKO, $6-7 \%$ shell, $12-14 \%$ fibre, $22-25 \%$ CPO were produced from palm oil fresh fruit bunch (FFB) also about $0.65 \mathrm{~m}^{3}$ produced per ton of FFB processed POME is the most substantial fraction of palm oil mill waste [2]. POME in a palm oil mill is generating by the clarification station $\left(0.39 \mathrm{~m}^{3}\right)$, POME is mostly treated with the open lagoon technology, as it is the most comfortable and cheapest disposal method, and the EFB dumped in the plantation as mulch [3].

One of the main problems in the utilisation of biomass waste in the collection due to its highly dispersed location [4]. Departing from the above, palm oil mill is a potential source of potential biomass waste that has been collected to reduce or eliminate collection costs, it occurs in Riau as the most significant producer of palm oil in Indonesia [5]. The Regulation of Ministry of Energy and Mineral Resources Indonesia, PT PLN (State Electricity
Company) should purchase electricity from renewable energy plant to strengthen the local power supply system. The purchase price of electricity IDR $975,-/ \mathrm{kWh}$ if interconnected to Medium Voltage and IDR 1,325, - / $\mathrm{kWh}$ if interconnected at Low Voltage [6].

Figure 1 describes The development of biogas power plants in Indonesia that contained in Government Regulation of the Minister of Energy and Mineral Resources of the Republic of Indonesia No. 12 of 2017 [7]. In Scheme A which is palm oil mills are responsible for Total Project on Upstream side. Then Scheme B cooperates with private companies, either in build operate - transfer (BOT) schemes or Build-Own-Operate (BOO) schemes and Scheme $\mathrm{C}$ is an alternative scheme that palm oil mills may adopt this scheme Investors only build biogas plant facilities without the need to convert into electricity.

The Sei Garo and Sei Galuh oil palm plants with fresh fruit bunch capacity 39.50 tons/hour, the treated wastewater produce biogas of about $538 \mathrm{~m} 3 / \mathrm{hr}$ or equivalent to 4,600 $\mathrm{MJ} / \mathrm{h}$ which potentially generate electricity around $1 \mathrm{MW}$ [8]. This paper discusses the POME Biogas Power Plant project scheme that benefits the palm oil mill which is Built-Operate-Transfer (BOT) [7]. Also, in this scheme as gas fuel to operate diesel generators [9][10][11] 


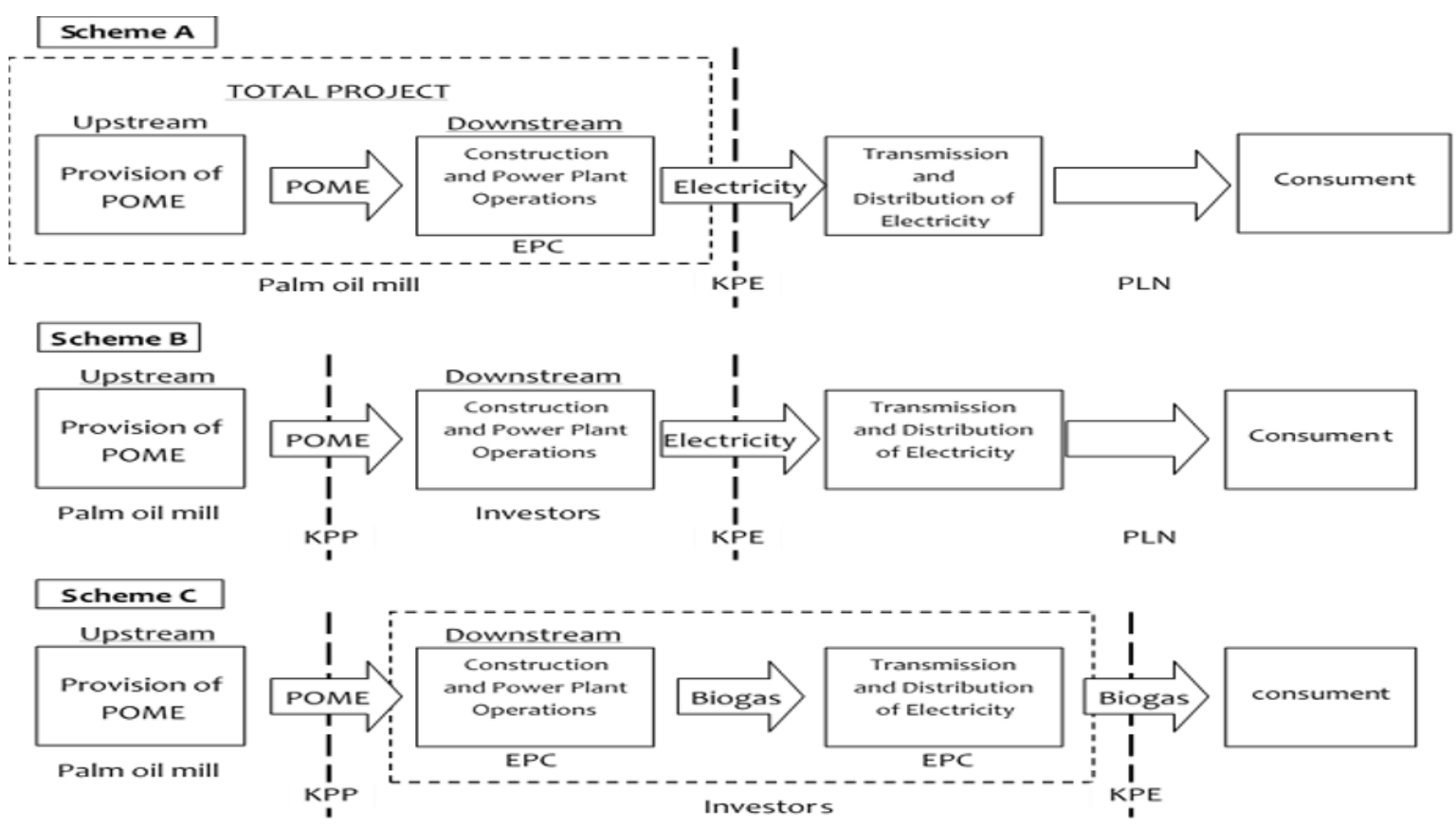

Figure 1. Development Scheme of biogas plant construction

\section{Evaluation of the Economy}

The Biogas Power Plant is evaluated using the Internal Rate of Return (IRR) method and is also the view from the period required to obtain a favourable balance sheet or Payback Period or Present Net Value (NPV) at the end of the BOT period. In this study discussed several alternatives of BOT duration, ranging from 5 years to 20 years with an interval of 5 years

\subsection{Data and calculation assumptions}

The lifetime of the gas engine is approximately 60,000 operating hours or around eight years with an assumed annual working hour of about 7,200 hours, while for HDPE-sheet used as a lagoon cover and skirt liner is about 15 years. The plant is assumed to have derated capacity from year 11 up to the 20th year to $98 \%$. Although the actual age of the plant can reach 20 years with a routine overhaul, for this financial assessment it is assumed that the operation of the plant is the same as the BOT period.

However, project funding uses $70 \%$ of loans and $30 \%$ equity. This funding scheme depends on the facilities provided by the Lender or the Bank and the proposed offer. POME raw materials supplied by oil palm mills with an average outflow of $435 \mathrm{~m}^{3} / \mathrm{hr}$. This amount is equivalent to $1280 \mathrm{~kW}$ of generated electrical energy. POME raw material analysis which is the input of generating system produces about $13.000 \mathrm{~m}^{3}$ / day. The content of $\mathrm{CH}_{4}$ in biogas is taken an average value of about $60 \%$. From these data, assuming the efficiency of Biogas Engine by $40 \%$ then obtained the amount of electric energy generation potential of $1.28 \mathrm{MW}$.

\subsection{Build-operate-transfer (BOT)}

BOT for five-years assumptions primary concludes that investment is not feasible to do. The biogas plant financial analysis with BOT duration for ten years shows in Graph 1. The balance sheet has started positively in the seventh year. However, the NPV at the end of BOT duration is still negative because the total discounted cash inflow (present value of total cash inflow) is even smaller than the current value of the invested investment.

Financial analysis Biogas plant with BOT duration for 14 years shows in Graph 1. The IRR value is $16.31 \%$ higher than the WACC limit requirement of $15.61 \%$. The project is feasible implemented because it obtained IRR of $17.47 \%$, higher than WACC which amounted to $15.61 \%$. Besides, loan payments are distributed within 15 years so that the annual instalment to be paid becomes small. The amount of this instalment effect on Generating Cost which for this scheme is in the range of IDR 827.37 / $\mathrm{kWh}$. If comparisons made with the electricity selling rate of IDR $975.00 / \mathrm{kWh}$, then there is sufficient margin for loan repayments. Under such conditions, the total financial balance was confident in the sixth year. Alternative plant shows that the duration of BOT for five years is feasible. The project is very reasonable implemented with a very high IRR $(37.56 \%)$ score when compared to WACC $(15.61 \%)$. The high Return on Investment in Alternative Projects manifested in the shortness of the return on equity invested by Investors. 


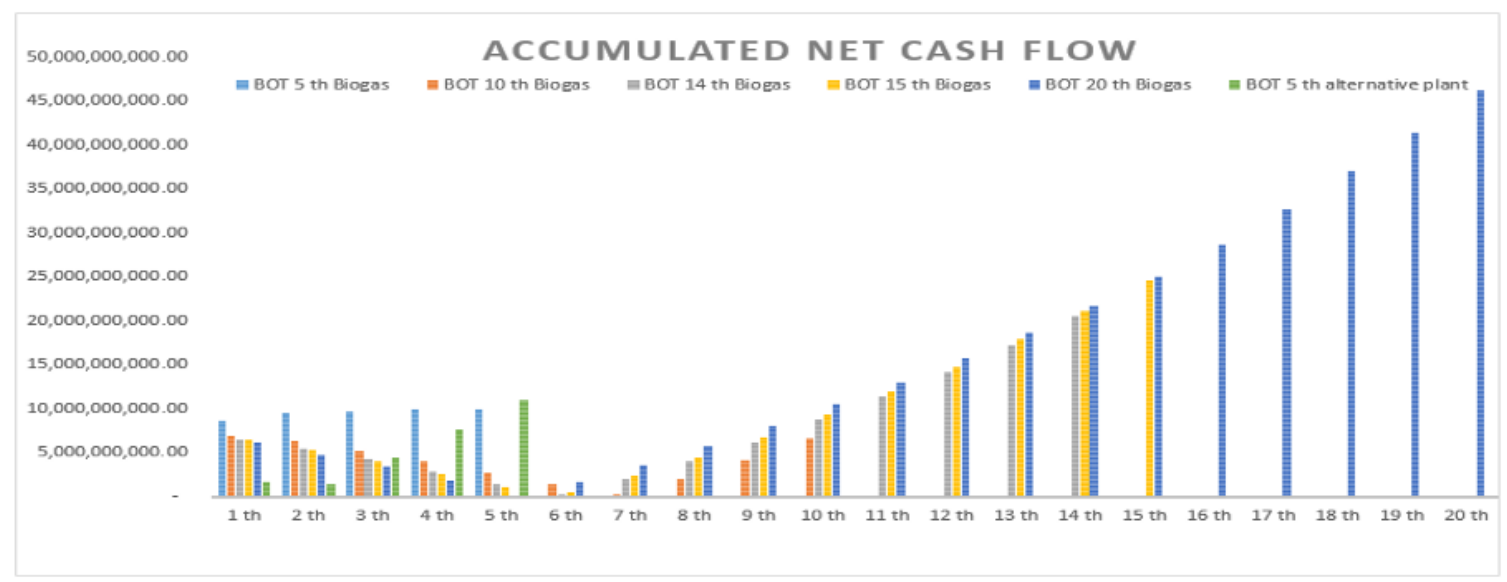

Graph 1. Build-operate-transfer (BOT) per years.

\subsection{Sensitivity Analysis}

The 5-year BOT of the project becomes feasible only if the investment cost lower by $50 \%$ this is relatively impossible to do. While the 10-year BOT The decrease of investment cost by $20 \%$ makes the project feasible to be implemented because of the IRR value obtained above WACC. However, the decline in investment costs of this magnitude is relatively painful to realise. The project also becomes feasible if the escalation of electricity tariff increase reaches $7 \%$ per year. Unlike the 14-year BOT, the vulnerable project becomes improper if there is an investment cost increase of about $10 \%$ because the IRR value falls on $12.79 \%$ below WACC of $15.61 \%$ which in turn leads to more extended payback period. A tariff escalation rate of only $2 \%$ per annum resulted in a $14.03 \%$ decrease in the IRR of the project. The same is true if borrowing rates rise to $13 \%$.

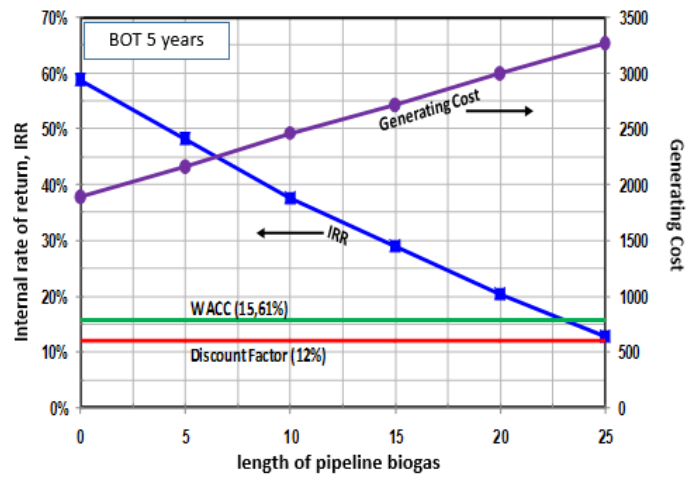

The 15-year BOT has an investment cost increase of up to $10 \%$ making the project unfeasible to be based on IRR value $(14.11 \%)$ lower than WACC $(15.61 \%)$. The escalating basics assumption of electricity tariff increase is $3 \%$ per year if this assumption decreased to $2 \%$, the project IRR value $(15.25 \%)$ becomes lower than WACC (15.61\%). The project is still feasible implemented if there is an increase of loan interest rate up to $13 \%$ because it even obtained IRR (16.27\%) higher than WACC (16.01\%) although Payback Period to 6.16 years from the original 5.63 years if the interest rate remains $12 \%$.

As for the Alternative Plant obtained a relatively very high IRR value of $37.57 \%$. The effect of the length of the biogas distribution pipeline network on the financial feasibility of the project. The longer the biogas pipeline will increase the investment cost. Figure 2, pipeline up to $23 \mathrm{~km}$ is still obtained the value of IRR financially feasible when compared with WAC.

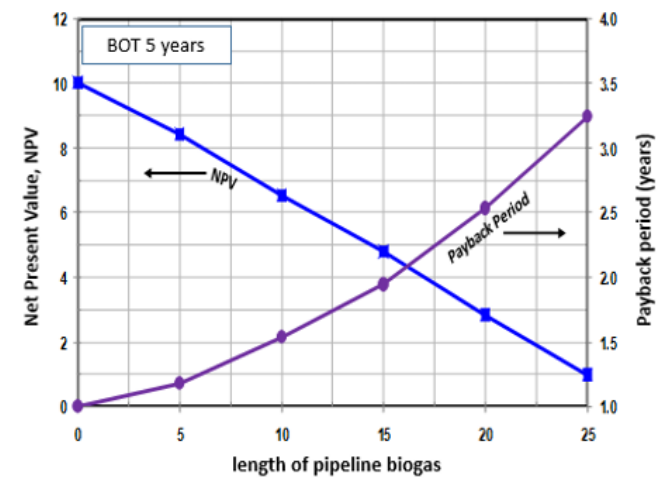

Figure 2 Effect of Biogas Pipe Network Length on IRR \& Generating Cost and Effect of Biogas Pipe Network Length on NPV \& Payback Period

During the 5-year BOT period, there are a potential savings of approximately IDR 13 billion per year. After the duration of BOT ends, after the 5th year, the savings gained increased to more than 20 billion per year. However, the only value is the cost of plant operation and maintenance. During the BOT period, the savings accumulated by the palm oil mill were more than IDR 60 billion and increased sharply after the completion of the BOT period, which in the 7 th year of plant operation obtained an accumulated savings of approximately IDR 11 billion. All of the 
above values are the value of money in the related year and not the time value of money

\section{Conclusion}

BOT scheme with a duration of 15 years selected as a reference with this duration obtained IRR of $17.47 \%$ higher than at WACC of $15.61 \%$ and payback period for 5.63 years. The 15 -year length gives Investor resilience in case of an increase of loan interest rate to $13 \%$ during the repayment period. Figure. 3, 14year BOT duration has also entered into an

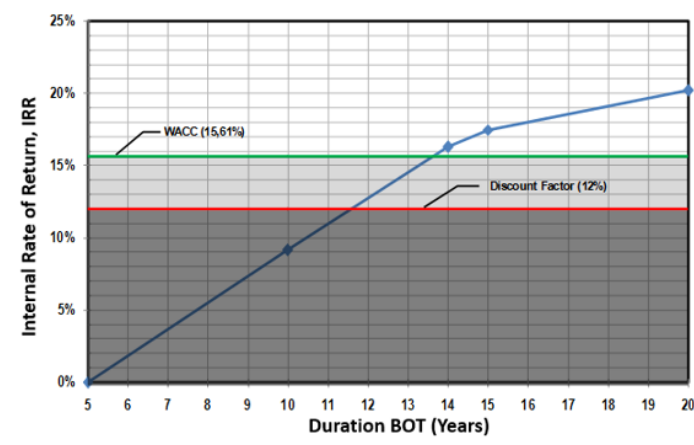

investment-worthy zone, but this duration does not provide safety margin as significant as BOT scheme duration 15 years in case of change of national economic condition. The payback period of fewer than six years is relatively good enough for 15 years of operation with NPV value based on current year amounting to more than 4 billion IDR. The accumulated revenue derived from the palm oil mill from profit sharing amounting to IDR $75.00 / \mathrm{kWh}$ during the 15 -year BOT period is IDR 9.6 billion which is the currency value in the 15 th year.

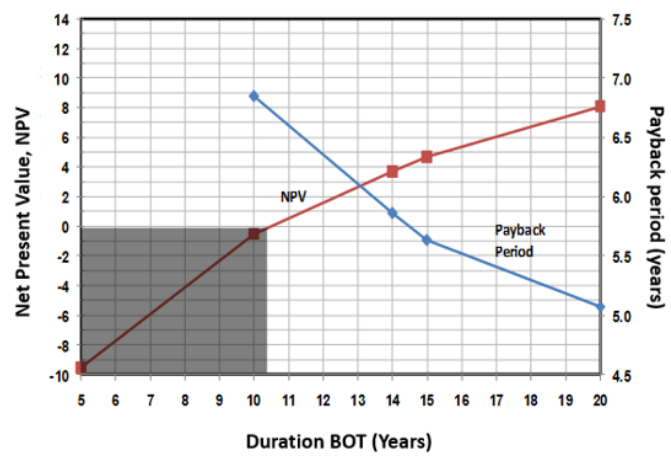

Figure 3. Effect of BOT Duration on IRR and Effect of BOT Duration on NPV and Payback Period

While the average annual income of the palm oil mill during the duration of BOT is around IDR 600 million after the handover of the plant in the fifteenth year, the yearly income of the palm oil mill jumps to more than IDR 5 billion per year. alternative scheme is also much more attractive to investors with a very high IRR value of $37.57 \%$ for 5-year BOT duration with payback period in only 1.5 year period.

\section{Acknowledgements}

The research described in this paper was financially supported by LPDP (Indonesia Endowment Fund for Education), Laboratory Fuel Technology and Engineering Design-(BTBRD) BPPT, and PTPN V (PERSERO), Republic Indonesia.

\section{References}

1. K. Abdul Rahman and A. Ramesh, "Effect of reducing the methane concentration on the combustion and performance of a biogas diesel predominantly premixed charge compression ignition engine," Fuel, vol. 206, pp. 117-132, 2017.

2. Y. Ahmed, Z. Yaakob, P. Akhtar, and K. Sopian, "Production of biogas and performance evaluation of existing treatment processes in palm oil mill effluent (POME)," Renew. Sustain. Energy Rev., vol. 42, pp. 1260-1278, 2015.

3. H. Ambarita, "Performance and emission characteristics of a small diesel engine run in dual- fuel (diesel-biogas) mode," Case Stud. Therm. Eng., vol. 10, no. June, pp. 179-191, 2017.

4. KEMEN ESDM, "Peraturan Menteri Energi dan Sumber Daya Mineral Republik Indonesia No. 12 Tahun 2017 Tentang Pemnafaatan Sumber Energi Terbarukan Untuk Penyediaan Tenaga Listrik," pp. 2-22, 2017.

5. M. Mohamed Ibrahim, J. Varuna Narasimhan, and A. Ramesh, "Comparison of the predominantly premixed charge compression ignition and the dual fuel modes of operation with biogas and diesel as fuels," Energy, vol. 89, pp. 990-1000, 2015.

6. M. A. Nasution, D. S. Wibawa, T. Ahamed, and R. Noguchi, "Comparative environmental impact evaluation of palm oil mill effluent treatment using a life cycle assessment approach: A case study based on composting and a combination for biogas technologies in North Sumatera of Indonesia," J. Clean. Prod., vol. 184, pp. 1028-1040, 2018.

7. PTPN V, "Data Tandan Buah Segar (TBS) Olah di Pabrik Kelapa Sawit PT Perkebunan Nusantara V," 2013.

8. K. Rajendran, H. R. Kankanala, R. Martinsson, and M. J. Taherzadeh, "Uncertainty over technoeconomic potentials of biogas from municipal solid waste (MSW): A case study on an industrial process," Appl. Energy, vol. 125, pp. 84-92, 2014.

9. H. Stichnothe and F. Schuchardt, "Life cycle assessment of two palm oil production systems," Biomass and Bioenergy, vol. 35, no. 9, pp. 39763984, 2011.

10. A. Sugiyono et al., Outlook Energi Indonesia 2016, no. July. 2016.

11. T. Wright and A. Rahmanulloh, "Indonesia Oilseeds and Products Update July 2016,” 2016. 